\title{
THE EFFECT OF SOCIO-CULTURAL FACTORS ON POLITICAL PARTICIPATION OF RURAL COMMUNITIES IN INDONESIA
}

\author{
Zainur Wula \\ Faculty of Social and Political Sciences, Muhammadiyah University of Kupang, \\ East Nusa Tenggara, Indonesia \\ E-mail: zainurwula32@gmail.com
}

\begin{abstract}
The purpose of this study was to analyze the influence of socio-cultural factors on the political participation of rural communities. The study was conducted in Ende District, East Nusa Tenggara. This study used qualitative methods with a case study approach. Data collection was done through observation, interviews, and documentation. The results of the study revealed that there were four social actions in political participation, namely instrumental rational, value-oriented rational, affective action, and traditional actions. There were five forms of political participation carried out by the community in the election, namely participation in exercising voting rights, participating in campaigns, participation in election committees, participation in inviting other parties and participation in the vote counting process.
\end{abstract}

\section{KEY WORDS}

Political participation, socio-cultural communities, public service, government.

Indonesia is a country that adheres to the notion of democracy. As a democratic country, the task of government involves the community in the implementation and enforcement of political decisions. Democratic parties in the form of general elections and choosing leaders still continue to run today (Knight K, 2002). The government also implements the Election of Regional Heads which provide opportunities for local people to elect their regional heads. The role of the community in determining policy and controlling government requires awareness and active political participation from the community. Political participation as an ordinary citizen activity influences the process of making and implementing public policy and participating in determining government leaders (Rahman 2002).

Political participation as an effort by citizens of the community both individually and in groups to participate in influencing the formation of public policy in a country (Gaffar 1998). Voter participation in Indonesia since the 1999 election until the 2014 election has fluctuated. In the legislative elections, a decline of voter participation of around $10 \%$ consistently occurred until the 2009 election. Meanwhile, in the 2014 election, the participation rate rose by $5 \%$. In the presidential election case, it was noted that in the 2014 elections for the first time in history the participation rate was lower than the legislative elections. Political participation is also very dependent on mission, program and ideology conformity (Henneberg, 2004).

Political participation is interpreted by developing issues such as economic, social, foreign influence, support, and leadership characteristics (Falkowski, 2002). The ability to communicate with voters or potential voters can increase people's political participation (Niffenegger 1989). Political parties and political figures always try to influence people's attitudes in making political choices. This can increase political participation. The motives of the social actions that underlie the community in participating in politics are different. Every community has a motive in making political participation. Differences in motives for political participation in society are often influenced by education, employment, and social strata. This difference in motives underlies various forms of political participation in general elections. The purpose of this study was to analyze the influence of socio-cultural factors on the political participation of rural communities. 


\section{METHODS OF RESEARCH}

This research was conducted in Ende District, East Nusa Tenggara, Indonesia. This study uses qualitative methods with a case study approach. this research was conducted from 2018-2019. The data used in this study are primary data and secondary data. Primary data is data obtained by researchers through observation, and in-depth interviews with respondents and informants directly at the study site. Observations were carried out by researchers by observing the physical condition and activities found at the study site. Analysis of qualitative data is carried out through four stages, namely data collection, data reduction, data presentation, and conclusion drawing. Qualitative research is carried out to complement data related to the motives of the political participation of the people in elections, forms of community political participation in elections, and the relationship between social actions and other forms of political participation in elections.

\section{RESULTS AND DISCUSSION}

Community Social Active Motives in Political Participation. In general, the socio-cultural factors of society are very influential on political culture and the level of political participation. Political culture in frequent sociological studies just emerging and coloring the current political contest, especially in rural communities. The socio-political process that takes place in the life of the Nuanaga village community is very closely related to the socio-cultural interactions that are created. Most socio-cultural factors have influenced the political participation of the people of the village of Nuanaga, Ende District. Thus, in the conduct of elections the village community produced different participation. The difference in participation is very much related to references and social actions.

In rural communities, elections are the motive for basic actions that influence political participation. According to Weber (2000), social action is divided into four types, namely actions with instrumental rational motives, actions with rational motives oriented to values, affective actions, and traditional actions. The motive for growing social actions in the Nuanaga village community makes a difference in political participation. The different motives of actions in political participation include: First, the motives of instrumental rational social actions, the motives of instrumental rational social actions are the motives of social actions based on rationality, consideration, and purpose.

In the Nuanaga village community, political participation is based on economic considerations in carrying out a social action. Political participation by the Nuanaga village community is based on economic achievements. According to Conway (1985: 20), in a society, the level of political participation tends to vary with socio-economic status. Those with higher education, earning more and having higher employment status are usually more participatory than those who are poor, uneducated and have low-status jobs. Second, rational motives are value-oriented, some of the Nuanaga villagers follow political participation based on certain social values in society. The social values are in the form of community awareness and the obligation of the leader based on the values adopted. Valueoriented rational motives are based on people's attitudes about the importance of getting the right leader. Most people have a high level of rational motive oriented tendency towards political participation in general election activities. Third, affective motives. Effective motives form the basis of the Nuanaga village community for political participation. Some people make elections based on emotional feelings and interests.

The affective motives possessed by the Nuanaga villagers in the election are related to the community's interest in participating in elections, the emotional closeness between the community and the candidates in elections, and the conduciveness of the social conditions of the community. The reason for this political participation tends to be non-national. When attending a general election, such as the election of a president, regional head or village head, it is not uncommon for people to be involved for affective emotional reasons. Fourth, traditional motifs. Traditional motives form the basis for some of the Nuanaga villagers to participate in political participation. Participation carried out by the community is based on 
people's adherence to traditions and customs. Traditional motifs are tied to the choice of religious teachings, customs, the suitability of background, the ethnicity of candidates, figures and institutions that influence in culture.

Political Participation of the Nuanaga Village Community. Higher political participation indicates that the community follows and understands and engages in state activities. Likewise, vice versa, low political participation indicates that the community is less interested in state activities. The form of political participation of the Nuanaga Village community in the Election of Regional Heads and General Elections can be divided into five forms. The five forms include the use of suffrage, involvement in campaigns, community involvement in voting, participation in inviting others, and participation in vote counting. First, participation uses voting rights. The people of Nuanaga Village participate by using voting rights.

The community is given the right to choose the candidate leaders. Automatically, this election is also a means of political participation that requires the community to be involved in it. According to Ediraras et al. (2013), the use of voting rights is expected to support various policies, and certain programs carried by candidates. Second, campaign political participation. Some of the Nuanaga villagers participated in the campaign. The community spends its time, energy, or mind to be involved in the campaign. Campaigns carried out by the community very, from social media promotions and coming to voters from home. Zachry (2009 ) said the model of conventional political campaigns had been replaced by social media presence. Ediraras et al. , (2013), said the election campaign was determined by the strategies applied by the candidates and parties to reach the voter target. Third, political participation in the form of voting. Some of the Nuanaga villagers participated in the voting. The form of voting participation by becoming the committee for the conduct of elections. the organizing committee for elections at the village level is divided into two categories, namely the Voting Committee (PPS) and the Voting Organizing Group (KPPS).

The Voting Committee (PPS) is an election committee at the village level. Members of the Voting Committee consisted of one village official and several community members who were trusted by the village elite to become the Voting Committee. People who are members of the Voting Committee are those who are selected based on the results of deliberations between village officials. Fourth, political participation in inviting other parties. The Nuanaga Village community partially participates in inviting others to participate in elections, such as reminding the community to exercise their right to vote, being involved in campaigns, participating as election committees, and participating in the voting process. Fifth, political participation in the form of vote counting.

The Nuanaga Village community involved in the vote counting process felt the need to know and witness who the candidates were elected. Although information about the candidates selected in the election can be known from the surrounding neighbors. some people feel the need to take part in a vote-counting process to witness the process of electing candidates. The reality is that the Nuanaga villagers live with political ambitions. This phenomenon can be seen in the lives of middle-class people who have the complexity of ambitions from economic and political aspects and often end in conflicts of interest. Conflict of interest often ends with disappointment because interests do not match the desired expectations. This kind of thing will create conflict within the group so that it has an impact on social ties.

\section{CONCLUSION}

There are factors that influence the political participation of rural communities in the village of Nuanaga. This factor is seen in the form of social action. The results of the study found four motives of social action in political participation, namely instrumental rational, value-oriented, affective, and traditional rationales. The results of the study also revealed that there were five forms of political participation carried out by the public in general elections, namely participation in voting rights, participating in campaigns, election committees, inviting others to participate, and participating in the vote counting process. 


\section{REFERENCES}

1. Chadwick A. 2013. The Hybrid Media System: Politics and Power. Virginia [US]: Oxford University Press.

2. Conway M. 1985. Political Participation in The United States. Washington [US]: Congressional Quarterly Inc.

3. Ediraras DT, Rahayu DA, Natalina A, Widya, W. 2013. Political marketing strategy of Jakarta governor election in the 2012s. Procedia- Social and Behavioral Science, 81: 584-587.

4. Falkowski A, Wojciech Cwalina. 2002. Structural Models of Voter Behavior in the 2000 Polish Presidential Election. Journal of political marketing. 1:2-3, 137-158.

5. Gaffar A. 1998. Merangsang partisipasi politik rakyat. Dalam, Syarofin Arba (Editor), Demitologi Politik Indonesia: Mengusung Elitisme dalam Orde Baru. Jakarta [ID]: Pustaka Cidesindo.

6. Henneberg Stephan C. M. 2004. Political Marketing Theory: Hendiadyoin or Oxymoron. University of Bath School of Management Working Paper Series.

7. Johnson-Cartee S, Copeland. 2004. Strategic Political Communication: Rethinking Social Influence, Persuasion, and Propaganda. Lanham: Rowman \& Littlefield.

8. Knight K, Marsh M. 2002. Varieties of election studies. Electoral Studies, 21(2): 157-366.

9. Johnson-Cartee S, Copeland. 2004. Strategic Political Communication: Kaid LL. 1999. Political advertising: A summary of research findings. Thousand Oaks (US): Sage.

10. Michels, Robert., 1968. Political Parties: A Sociological Study of the Oligarchical Tendency of Modern Democracy. London: Free Press.

11. Niffenegger. 1989. Strategies for Success from the Political Marketers. Journal of consumer marketing. Vol 6 Iss 1 pp 45-51.

12. Parsons T. 1940. An analytical approach to the theory of social. The American Journal of Sociology.

13. Rahman A. 2002. Sistem Politik Indonesia dalam Perspektif Struktural Fungsional. Surabaya [ID]: Penerbit SIC.

14. Weber, M. (2000), Sociology from Max Weber, (terj.). Yogyakarta: Pustaka Pelajar.

15. Zachry C. 2009. Political campaign and new media: A changing landscape www.scripps.ohiou.edu/media/ podcasts/j416/papers/zachry.pdf. 